\title{
Risk Assessment of Wave Energy Converter At Kuantan Port, Pahang
}

\author{
Muhammad Asyraf Abdullaha, Noh Zainal Abidin ${ }^{b}$, Zulkifly \\ Mat Radzi ${ }^{b}$, Mohd Arif Ahmad ${ }^{b}$, Vikneswaran Munikanana, \\ Mohd Norsyarizad Razalib, Neza Ismaila
}

Harvesting energy from ocean waves remains an untapped resource, and it is considered a new methodology in renewable energy, especially in Malaysia. This research is based on a project at Kuantan Port that used Wave Energy Converter (WEC) as a platform to generate energy from waves and convert it into electricity. The purpose of this research is to conduct a risk assessment before the execution of the project by referring to the International Organization for Standardization (ISO) 31000 and Risk Management Guidelines: Companion to AS/NZS 4360:2004. It started from risk identification and planned a mitigation way to reduce the grade of risk. These mitigations will be monitored throughout the project to avoid any accidents or harm during construction and installation in the future. The assessment will be using a qualitative analysis method that will gather all the possible risks that impact the project and propose the actions to

\section{KEY WORDS}

$\sim$ Renewable Energy

$\sim$ Wave Energy Converter

$\sim$ Risk Assessment

$\sim$ Risk Mitigation

$\sim$ Qualitative Analysis

\footnotetext{
a. National Defence University of Malaysia, Faculty of Engineering e-mail: asyraf.abdullah93@gmail.com

b. National Defense University of Malaysia, Faculty of Science and Defense Technology e-mail:zulkifly@upnm.edu.my

doi: 10.7225/toms.v10.n02.002

This work is licensed under (cc) BY
}

Received on: 11.06.2021 / Revised on: 29.07.2021 / Accepted on: 19.10.2021 / Published: 21.10.2021 mitigate the risk. The assessment will also consider the likelihood, seriousness, and weightage to determine the risk level. The risk assessment is divided into six clusters: project management, hydrography, mechanical, electrical, civil, and safety and security. After analysis, each cluster has given their feedback on the risk assessment and their cluster-s risk grade. This research has found that the risk grade is at grade $C$, which needs the risk assessment of this project to reduce the likelihood, seriousness, and required mitigation actions. Eventually, after the mitigation plan is applied to each risk, the grade of risk is reduced to $\mathrm{N}$.

\section{INTRODUCTION}

Renewable energy has emerged to become an integral option to replace traditional options, fossilized fuel. Ocean waves have been proved to evolve as a marine renewable energy source, and harvesting energy remains an untapped resource. It is still considered a new methodology in renewable energy, especially in Malaysia. It is estimated that harvesting energy from waves can supply approximately 1 and 1.5 times the world's consumption. However, most of this resource is currently technically unreachable or located remotely from the human community, and only $10 \%$ to $25 \%$ of electricity may be realistically generated from it (Ferro, 2006).

The marine renewable energy industry is about $10-15$ years behind the wind renewable energy industry. The technology is still considered new, and there would be many obstacles within it, such as its predictability, manufacturability, installability, operability, survivability, reliability, and affordability (Mueller \& Wallace, 2008).

Since the industry and technology are somewhat new, there will be many indecisions, thus creating risks. Risks can 
be described as the chance of something happening that will impact the objectives and often specified in terms of an event or circumstance and the consequences that may result from it (AS/ NZS4360, 2004).

Risk assessment and analysis are applied as a vital decision support tool to predict all the uncertainties, anticipate the probable outcome, and establish guided mitigating procedures (Okoro et al., 2017). It can be commenced with variable degrees of detail and complexity, reliant on the purpose of the analysis, the availability and dependability of the information, and the resources existing. Analysis methods can be qualitative, quantitative, or combined, depending on the situations and planned use (BSI, 2018). Therefore, an adequate risk assessment is required to mitigate the risks that emerge from the uncertainties. The risk assessment flow consists of identifying risks, as well as analyzing, evaluating, and mitigating them.

This research is based on UPNM's project at Kuantan Port that has used Wave Energy Converter (WEC) as a platform to harvest energy from ocean waves and convert it into electricity. A risk assessment is conducted before the project's execution and will act as initial risk identification. It is then to be mitigated and then compared before and after the mitigation. The risk assessment is divided into six clusters: project management, hydrography, mechanical, electrical, civil, and security and safety. However, there have been limitations to this research. Considering the risk assessment is conducted before the project's execution, and the list of the risks is through brainstorming sessions between the team, there are maybe risks that are not listed and are not expected to happen. The newer risks will be updated and registered in the future.

\section{METHODOLOGY}

The qualitative analysis utilizes words to represent the potential outcome's Seriousness and the Likelihood that the outcome will occur. It may be used as a preliminary measure to identify risks that require a more thorough analysis. The analysis is suitable for decisions or where the numerical data or resources are inadequate for a quantitative analysis (AS/NZS4360, 2004).

The qualitative analysis assessment method is crucial to decide the significance of risks and identify which ones need to be treated before other risks. It relies on some computational and graphical tools (Keshk et al., 2018).

Using qualitative analysis allows for identifying the risk's priority, provides for the determination of areas of more considerable risk in a short time and without more significant expenditures, and the analysis is comparatively easy and inexpensive (Sung, 2015). Meanwhile, the drawback of using qualitative analysis is that it does not allow for allocating likelihoods and results by using numerical methods. The cost-benefit analysis is more difficult during the selection of mitigations (Sung, 2015).

A matrix of Seriousness and Likelihood can define the risk to decide the grading for each risk that will provide a ranking of the project risk exposure at the time of the assessment.

The term likelihood refers to the probability of something happening, whether defined, measured, or decided objectively or subjectively, qualitatively or quantitatively, or defined using general terms or mathematics (Standard, 2014). Seriousness is a term of the consequence of an event that will be affecting goals, can lead to a range of Seriousness, can be sure or unsure, and can have positive or negative effects on the plans. It can be expressed qualitatively or quantitatively, and initial consequences can heighten through knock-on effects (Standard, 2014).

For this research, the Likelihood and Seriousness rating for each risk is shown in Table 1 and Table 2, respectively.

Table 1.

Rating for Likelihood for each risk (AS/NZS4360, 2004).

Descriptive Definition

High It can be predicted to occur during the project

\begin{tabular}{ll}
\hline Medium & Not predicted to occur during the project \\
\hline Low & $\begin{array}{l}\text { Plausible but highly unlikely to occur } \\
\text { during the project }\end{array}$ \\
\hline
\end{tabular}

Table 2.

Rating for Seriousness for each risk (AS/NZS4360, 2004).

\begin{tabular}{ll} 
Descriptive & Definition \\
\hline Extreme & Most objectives cannot be accomplished \\
\hline High & $\begin{array}{l}\text { Some important objectives cannot be } \\
\text { accomplished }\end{array}$ \\
\hline Medium & Some objectives affected \\
\hline Low & Slight effects that are easily mitigated \\
\hline
\end{tabular}


A rating of the risk rating is determined by the combination matrix of the rating level for Likelihood and Seriousness rating. The combination matrix is shown in Table 3.

Grading of the risk is identified by the combination of rating for Likelihood and Seriousness. The grade is rated from Grade A, $B, C, D$, and $N$. The grade is then weighted as numerical values to ease determining the grade for the project's overall risks and the mitigation actions that need to be taken. The weightage values are rated from 5, 4, 3, 2, and 1, respectively. The grade of the risk is shown in Table 4.
Table 3.

Combination matrix for grading of risk (AS/NZS4360, 2004).

\begin{tabular}{|c|c|c|c|c|c|}
\hline \multirow{5}{*}{ 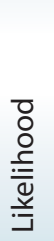 } & \multicolumn{5}{|c|}{ Seriousness } \\
\hline & & Low & Medium & High & Extreme \\
\hline & Low & $\mathrm{N}$ & $\mathrm{D}$ & $\mathrm{C}$ & $A$ \\
\hline & Medium & $\mathrm{D}$ & C & B & A \\
\hline & High & $\mathrm{C}$ & B & $A$ & $A$ \\
\hline
\end{tabular}

Table 4.

Rating for the grade of the risk (AS/NZS4360, 2004).

\begin{tabular}{lll} 
Grade & Risk mitigation actions & Weighted \\
\hline A & $\begin{array}{l}\text { Mitigation actions, to decrease the Likelihood and Seriousness, to be identified and } \\
\text { implemented as soon as the project commences as a priority }\end{array}$ & 5 \\
\hline B & $\begin{array}{l}\text { Mitigation actions, to decrease the Likelihood and Seriousness, to be identified and } \\
\text { appropriate measures implemented during project execution }\end{array}$ & 4 \\
\hline C & $\begin{array}{l}\text { Mitigation actions, to decrease the Likelihood and Seriousness, to be identified and } \\
\text { evaluated concerning costs for possible action if funds permit }\end{array}$ & 3 \\
\hline D & To be noted - no action is needed unless grading increases over time & 2 \\
\hline N & To be noted - no action is needed unless grading increases over time & 1 \\
\hline
\end{tabular}

\section{RESULT AND ANALYSIS}

For this research, there are six clusters involved in the project: Project Management Team, Hydrography Team, Mechanical Team, Electrical Team, Civil Team, and Security and Safety Team. Each cluster is assigned to one leader and a team consisting of five team members.

For the risk assessment, each team leader and their members are needed to determine the risks for their respective team, assess the impact of the risks to the project, give grading to the risks before mitigation is performed, determine the mitigation actions that need to be done to contain the risks, and give back the rating of grading of the risks after mitigation steps have occurred. The total grading of the project risks for each cluster is determined from the total grade average. Some of the risks from each cluster are shown in the tables below. 
Table 5.

Risk on Project Management Team.

BEFORE

AFTER MITIGATION

MITIGATION

\begin{tabular}{|c|c|c|c|c|c|c|c|c|c|c|c|}
\hline ID & $\begin{array}{l}\text { DESCRIPTION OF } \\
\text { RISK }\end{array}$ & IMPACT ON PROJECT & $\mathbf{L}$ & $S$ & G & $\mathbf{w}$ & MITIGATION ACTIONS & $\mathbf{L}$ & S & G & w \\
\hline 1 & $\begin{array}{l}\text { Hazards during } \\
\text { construction and } \\
\text { transportations at sea }\end{array}$ & $\begin{array}{l}\text { Lead to worker } \\
\text { accidents and injuries }\end{array}$ & $M$ & $M$ & $C$ & 3 & $\begin{array}{l}\text { Supplier responsibility in } \\
\text { contract }\end{array}$ & $\mathrm{L}$ & $L$ & $\mathrm{~N}$ & 1 \\
\hline 2 & $\begin{array}{l}\text { Damage or theft to } \\
\text { equipment and tools }\end{array}$ & $\begin{array}{l}\text { Effects on the process } \\
\text { of construction and } \\
\text { installation }\end{array}$ & $M$ & $M$ & $C$ & 3 & $\begin{array}{l}\text { Supplier responsibility in } \\
\text { contract }\end{array}$ & $\mathrm{L}$ & $\mathrm{L}$ & $\mathrm{N}$ & 1 \\
\hline 3 & $\begin{array}{l}\text { Natural disasters, e.g., } \\
\text { Typhoon, Monsoon }\end{array}$ & $\begin{array}{l}\text { The breakwater and } \\
\text { ships nearby may } \\
\text { be hit by the WEC } \\
\text { platform }\end{array}$ & $M$ & $\mathrm{H}$ & B & 4 & $\begin{array}{l}\text { Dual safety design } \\
\text { element }\end{array}$ & L & $M$ & $D$ & 2 \\
\hline
\end{tabular}

\begin{tabular}{|c|c|c|c|c|c|c|c|c|c|c|c|}
\hline 4 & $\begin{array}{l}\text { No ownership of } \\
\text { the project after } \\
\text { completion for } \\
\text { operation and } \\
\text { maintenance of WEC }\end{array}$ & $\begin{array}{l}\text { No responsible parties } \\
\text { to take over the project } \\
\text { after completion }\end{array}$ & L & $M$ & $\mathrm{D}$ & 2 & $\begin{array}{l}\text { Obtaining specific } \\
\text { agreement with KETSA } \\
\text { on post-construction } \\
\text { ownership and } \\
\text { maintenance }\end{array}$ & L & $\mathrm{L}$ & $\mathrm{N}$ & 1 \\
\hline \multirow[t]{2}{*}{5} & $\begin{array}{l}\text { Loose WEC platform } \\
\text { may block the channel } \\
\text { of Kuantan Port }\end{array}$ & $\begin{array}{l}\text { Effect on Kuantan Port } \\
\text { productivity in terms } \\
\text { of number of ships } \\
\text { coming alongside }\end{array}$ & L & $M$ & $\mathrm{D}$ & 2 & $\begin{array}{l}\text { The mooring chain } \\
\text { design for WEC can } \\
\text { withstand Extreme Wave } \\
\text { Condition and hold the } \\
\text { WEC as firm as possible. } \\
\text { Besides, the location } \\
\text { of WEC is outside the } \\
\text { breakwater, not on the } \\
\text { ship }\end{array}$ & L & $\mathrm{L}$ & $\mathrm{N}$ & 1 \\
\hline & & $\begin{array}{l}\text { Project grade of risk } \\
\text { before mitigation }\end{array}$ & 2.8 & & & & $\begin{array}{l}\text { Project grade of risk } \\
\text { after mitigation }\end{array}$ & 1.2 & & & \\
\hline
\end{tabular}


Table 6.

Risk on Hydrography Team.

BEFORE MITIGATION

AFTER MITIGATION

\begin{tabular}{|c|c|c|c|c|c|c|c|c|c|c|c|}
\hline ID & $\begin{array}{l}\text { DESCRIPTION } \\
\text { OF RISK }\end{array}$ & $\begin{array}{l}\text { IMPACT ON } \\
\text { PROJECT }\end{array}$ & $\mathbf{L}$ & $\mathbf{S}$ & G & $\mathbf{w}$ & MITIGATION ACTIONS & $\mathbf{L}$ & $\mathbf{S}$ & G & w \\
\hline 1 & $\begin{array}{l}\text { Validity and } \\
\text { reliability of } \\
\text { Oceanography } \\
\text { Data Collected } \\
\text { in terms } \\
\text { of Depth, } \\
\text { Wave Period, } \\
\text { Wave Height, } \\
\text { Current, Tide, } \\
\text { Weather }\end{array}$ & $\begin{array}{l}\text { The design } \\
\text { of WEC will } \\
\text { be affected } \\
\text { and will not } \\
\text { comply with } \\
\text { the WEC } \\
\text { specification } \\
\text { requirement }\end{array}$ & M & M & C & 3 & $\begin{array}{l}\text { The data collection and modeling have } \\
\text { to be carried out by a qualified person } \\
\text { and validated by Project Team - Team } \\
\text { Leader is a Qualified Hydrographic } \\
\text { Surveyor Category A }\end{array}$ & $\mathrm{L}$ & $\mathrm{L}$ & $\mathrm{N}$ & 1 \\
\hline 2 & $\begin{array}{l}\text { The quality } \\
\text { and credibility } \\
\text { of the } \\
\text { hydrography } \\
\text { surveyor } \\
\text { standard }\end{array}$ & $\begin{array}{l}\text { The data } \\
\text { obtained is } \\
\text { not reliable }\end{array}$ & $\mathrm{L}$ & $M$ & $\mathrm{D}$ & 2 & $\begin{array}{l}\text { The data collection and modelling } \\
\text { have to be carried out by a qualified } \\
\text { person and validated by Project Team } \\
\text { - Validation has been carried out by } \\
\text { Project Team Leader who is a Qualified } \\
\text { Hydrographic Surveyor Category A }\end{array}$ & $\mathrm{L}$ & $\mathrm{L}$ & $\mathrm{N}$ & 1 \\
\hline 3 & $\begin{array}{l}\text { Calibration of } \\
\text { instruments } \\
\text { and measuring } \\
\text { tools used }\end{array}$ & $\begin{array}{l}\text { It will affect } \\
\text { the reliability } \\
\text { and accuracy } \\
\text { of data } \\
\text { collected }\end{array}$ & $\mathrm{L}$ & $M$ & $\mathrm{D}$ & 2 & $\begin{array}{l}\text { The equipment used is calibrated and } \\
\text { function well before data collection. } \\
\text { The accuracy standard is as follows: } \\
\text { - Velocity Accuracy: } 1 \% \text { of measured } \\
\text { value } \pm 0.5 \mathrm{~cm} \\
\text { - Wave Height Accuracy: }<1 \% \text { of the } \\
\text { measured value } \\
\text { - Compass Accuracy: } 2^{\circ} \\
\text { - Pressure Accuracy: } 0.5 \% \text { of full scale } \\
\text { - Temperature Accuracy: } 0.1^{\circ} \mathrm{C}\end{array}$ & & & & \\
\hline
\end{tabular}

\begin{tabular}{|c|c|c|c|c|c|c|c|c|c|c|c|}
\hline 4 & $\begin{array}{l}\text { Suitability } \\
\text { of WEC site } \\
\text { location }\end{array}$ & $\begin{array}{l}\text { Unable to } \\
\text { obtain the } \\
\text { required } \\
\text { depth } \\
\text { and wave } \\
\text { characteristics } \\
\text { for operation } \\
\text { ability of WEC }\end{array}$ & L & M & $\mathrm{D}$ & 2 & $\begin{array}{l}\text { Site suitability identification was } \\
\text { made using modelling, carried out } \\
\text { by the Meteorology Department and } \\
\text { on-site data collection to confirm the } \\
\text { modelling result. } \\
\text { - Water depth range: } 15.07 \mathrm{~m} \text { to } 17.18 \mathrm{~m} \\
\text { - Wave peak period range: } 2.18 \mathrm{~s} \text { to } \\
15.52 \mathrm{~s} \\
\text { - Significant wave height range: } 0.14 \mathrm{~m} \\
\text { to } 1.10 \mathrm{~m}\end{array}$ & & & & \\
\hline \multirow[t]{2}{*}{5} & $\begin{array}{l}\text { Disturbance to } \\
\text { ecosystem }\end{array}$ & $\begin{array}{l}\text { It will } \\
\text { affect the } \\
\text { ecosystem of } \\
\text { surrounding } \\
\text { areas (sea } \\
\text { heritage) }\end{array}$ & L & M & $\mathrm{D}$ & 2 & Shall be assessed by research method & $\mathrm{L}$ & $\mathrm{L}$ & $\mathrm{N}$ & 1 \\
\hline & & $\begin{array}{l}\text { Project grade } \\
\text { of risk before } \\
\text { mitigation }\end{array}$ & 2.2 & & & & Project grade of risk after mitigation & 1.0 & & & \\
\hline
\end{tabular}


Table 7.

Risk on Mechanical Team.

BEFORE MITIGATION

AFTER MITIGATION

\section{ID DESCRIPTION IMPACT ON PROJECT} OF RISK

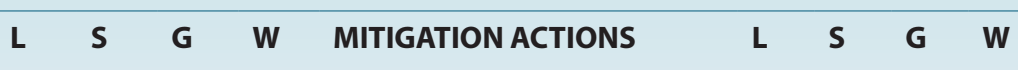

1 The failure of

Unable to achieve the mechanical parts to sufficient power output produce the required torque output to the motor

of WEC

$\begin{array}{llll}\mathrm{L} & \mathrm{L} & \mathrm{N} & 1\end{array}$

The location's actual wave characteristics need to be

$\begin{array}{llll}\mathrm{L} & \mathrm{L} & \mathrm{N} & 1\end{array}$ finalized, and the overall system is to be designed according to the estimated output. Irregular wave conditions at sea should produce higher output compared to the theoretical calculations
2 The corrosion of It will cause severe WEC platform defects to the WEC hull due to seawater plating, can cause the condition WEC to be capsized and

$\begin{array}{llll}M & \mathrm{H} & \mathrm{B} & 4\end{array}$

4

(
sink

M

$\begin{array}{lllll}\text { Layering and coating the WEC } & \mathrm{L} & \mathrm{L} & \mathrm{N} & 1\end{array}$ platform and the equipment with anti-rust paint and zinc anode

3 Mooring cable Lead to mooring line corroded and breakage and harm parted to the ships and port nearby due to collision

M E A 5

Layering and coating the mooring line and the equipment with anti-rust paint and with a detailed mooring line analysis by an experienced industry partner

\begin{tabular}{|c|c|c|c|c|c|c|c|c|c|c|c|}
\hline 4 & $\begin{array}{l}\text { Instability of } \\
\text { WEC and risk of } \\
\text { capsize }\end{array}$ & Lead to WEC sink & $\mathrm{L}$ & $\mathrm{H}$ & C & 3 & $\begin{array}{l}\text { HAT and SAT is to be carried } \\
\text { out on installations to ensure } \\
\text { that they are safe and meet } \\
\text { the design requirements } \\
\text { before commissioning }\end{array}$ & L & M & $\mathrm{D}$ & 2 \\
\hline \multirow[t]{2}{*}{5} & $\begin{array}{l}\text { WEC unable to } \\
\text { withstand to } \\
\text { Extreme Wave } \\
\text { Condition due } \\
\text { to Monsoon or } \\
\text { Typhoon }\end{array}$ & $\begin{array}{l}\text { Broken and damaged } \\
\text { WEC and can cause a } \\
\text { collision to ships and } \\
\text { port nearby }\end{array}$ & L & $E$ & $A$ & 5 & $\begin{array}{l}\text { HAT and SAT are to be carried } \\
\text { out on installations to ensure } \\
\text { that they are safe and meet } \\
\text { the design requirements. } \\
\text { Stability analysis on the WEC } \\
\text { by naval architect based on } \\
\text { the extreme wave conditions } \\
\text { analysis }\end{array}$ & L & M & $\mathrm{D}$ & 2 \\
\hline & & $\begin{array}{l}\text { Project grade of risk } \\
\text { before mitigation }\end{array}$ & 3.6 & & & & $\begin{array}{l}\text { Project grade of risk after } \\
\text { mitigation }\end{array}$ & 1.4 & & & \\
\hline
\end{tabular}


Table 8.

Risk on Electrical Team.

BEFORE MITIGATION

AFTER MITIGATION

\begin{tabular}{|c|c|c|c|c|c|c|c|c|c|c|c|}
\hline ID & $\begin{array}{l}\text { DESCRIPTION } \\
\text { OF RISK }\end{array}$ & IMPACT ON PROJECT & $\mathbf{L}$ & $\mathbf{S}$ & G & $\mathbf{W}$ & MITIGATION ACTIONS & $\mathbf{L}$ & $\mathbf{S}$ & $\mathbf{G}$ & W \\
\hline 1 & $\begin{array}{l}\text { The power } \\
\text { generation } \\
\text { system fails to } \\
\text { generate the } \\
\text { required output } \\
\text { power }\end{array}$ & $\begin{array}{l}\text { Unable to achieve the } \\
\text { necessary power output } \\
\text { and will need the power } \\
\text { supply support from } \\
\text { Kuantan Port }\end{array}$ & $\mathrm{H}$ & $\mathrm{H}$ & $A$ & 5 & $\begin{array}{l}\text { Hybrid with the solar panel } \\
\text { which can provide an } \\
\text { alternative power source. } \\
\text { The power generator } \\
\text { must be tested with a } \\
\text { WEC prototype so that the } \\
\text { output can be predicted } \\
\text { and selection of a suitable } \\
\text { size generator for the actual } \\
\text { application made. }\end{array}$ & $\mathrm{L}$ & $\mathrm{L}$ & $\mathrm{N}$ & 1 \\
\hline
\end{tabular}

2 Motor generator WEC unable to operate wear and tear

L $\quad$ E $\quad A \quad 5$

Use a special casing of

$\begin{array}{llll}\mathrm{L} & \mathrm{L} & \mathrm{N} & 1\end{array}$

due to seawater

condition

marine spec to avoid

corrosion. IP65 Steel

Enclosures, Electrical

Enclosure Standard:

IEC62208, IEC/EN/AS6052

3 The underwater Lead to current leakage L $\quad$ E A 5 Fabricate with a particular cable is that harms the aquatic outer layer of cable which defective and flora and fauna. Will disconnected interfere with the shipping route and port activities can sustain the impact with a maximum of $200 \mathrm{MPa}$

\begin{tabular}{|c|c|c|c|c|c|c|c|c|c|c|c|}
\hline 4 & $\begin{array}{l}\text { Stator winding/ } \\
\text { coil (motor) is } \\
\text { defective }\end{array}$ & Unable to generate power & $\mathrm{L}$ & $\mathrm{H}$ & $\mathrm{C}$ & 3 & $\begin{array}{l}\text { Ensure the generator spec } \\
\text { according to marine use, } \\
\text { which is } 3 \text { phase induction } \\
\text { generators with compliance } \\
\text { built to IEC } 60034 \\
\text { international classification }\end{array}$ & $\mathrm{L}$ & $\mathrm{L}$ & $\mathrm{N}$ & 1 \\
\hline \multirow[t]{2}{*}{5} & $\begin{array}{l}\text { Low insulation } \\
\text { of the electrical } \\
\text { system }\end{array}$ & $\begin{array}{l}\text { Lead to current leakage } \\
\text { and harm the life span of } \\
\text { motor-generator }\end{array}$ & $\mathrm{L}$ & M & $\mathrm{D}$ & 2 & $\begin{array}{l}\text { The design must follow the } \\
\text { TNB requirement }\end{array}$ & $\mathrm{L}$ & $\mathrm{L}$ & $\mathrm{N}$ & 1 \\
\hline & & $\begin{array}{l}\text { Project grade of risk } \\
\text { before mitigation }\end{array}$ & 4.0 & & & & $\begin{array}{l}\text { Project grade of risk after } \\
\text { mitigation }\end{array}$ & 1.0 & & & \\
\hline
\end{tabular}


Table 9.

Risk on Civil Team.

BEFORE MITIGATION

AFTER MITIGATION

\begin{tabular}{|c|c|c|c|c|c|c|c|c|c|c|c|}
\hline ID & $\begin{array}{l}\text { DESCRIPTION OF } \\
\text { RISK }\end{array}$ & IMPACT ON PROJECT & $\mathbf{L}$ & $\mathbf{S}$ & G & $\mathbf{W}$ & MITIGATION ACTIONS & $\mathbf{L}$ & $S$ & G & $\mathbf{W}$ \\
\hline 1 & $\begin{array}{l}\text { Unstable mounting } \\
\text { of cable layout on } \\
\text { the breakwater } \\
\text { structure }\end{array}$ & $\begin{array}{l}\text { The cable will } \\
\text { deteriorate and be } \\
\text { damaged, possibly } \\
\text { lead to a current } \\
\text { leakage }\end{array}$ & $\mathrm{L}$ & $\mathrm{H}$ & $C$ & 3 & $\begin{array}{l}\text { Testing and commissioning } \\
\text { is to be carried out on } \\
\text { installations to ensure that } \\
\text { they are safe and meet the } \\
\text { design requirement }\end{array}$ & $\mathrm{L}$ & $\mathrm{L}$ & $\mathrm{N}$ & 1 \\
\hline 2 & $\begin{array}{l}\text { Improper } \\
\text { submarine cable } \\
\text { mounting on the } \\
\text { seabed }\end{array}$ & $\begin{array}{l}\text { Unable to hold the } \\
\text { position of submarine } \\
\text { cable and lead the } \\
\text { cable towards WEC. } \\
\text { It will also increase } \\
\text { tension and stress on } \\
\text { the cable and lead to } \\
\text { cable fracture }\end{array}$ & M & $M$ & C & 3 & $\begin{array}{l}\text { Provide suitable length to } \\
\text { uphold the tension and } \\
\text { stress during the design }\end{array}$ & $\mathrm{L}$ & $\mathrm{L}$ & $\mathrm{N}$ & 1 \\
\hline
\end{tabular}

3 Bad mounting of mooring block on the sea bed
Changes in the positioning of the anchor block will affect the operation of WEC, create tension force on the mooring cable, thus risking it being broken

$\begin{array}{lllllllll}\mathrm{L} & \mathrm{H} & \mathrm{C} & 3 & \begin{array}{l}\text { Prepare expert's advice } \\ \text { during the construction }\end{array} & \mathrm{L} & \mathrm{L} & \mathrm{N} & 1\end{array}$

\section{$4 \quad$ WEC platform} collide with the breakwater structure

$\begin{aligned} & \text { WEC slamming to the } \\ & \text { breakwater structure } \\ & \text { and damaging the } \\ & \text { whole WEC platform, }\end{aligned}$
and

and the breakwater

structure

\begin{tabular}{|c|c|c|c|c|c|c|c|c|c|c|c|}
\hline 5 & $\begin{array}{l}\text { The location of the } \\
\text { mooring block at } \\
\text { the seabed is not } \\
\text { suitable }\end{array}$ & $\begin{array}{l}\text { Will affect the } \\
\text { operation of WEC and } \\
\text { be unable to achieve } \\
\text { sufficient power } \\
\text { output }\end{array}$ & $\mathrm{L}$ & $M$ & $\mathrm{D}$ & 2 & $\begin{array}{l}\text { Do a thorough investigation } \\
\text { of the seabed surface } \\
\text { before installation }\end{array}$ & $\mathrm{L}$ & $\mathrm{L}$ & $\mathrm{N}$ & 1 \\
\hline
\end{tabular}

$\begin{array}{llll}\begin{array}{l}\text { Project grade of risk } \\ \text { before mitigation }\end{array} & 2.8 & \begin{array}{l}\text { Project grade of risk after } \\ \text { mitigation }\end{array} & 1.0\end{array}$


Table 10.

Risk on Safety and Security Team.

\section{BEFORE MITIGATION}

AFTER MITIGATION

\begin{tabular}{|c|c|c|c|c|c|c|c|c|c|c|c|}
\hline ID & $\begin{array}{l}\text { DESCRIPTION OF } \\
\text { RISK }\end{array}$ & $\begin{array}{l}\text { IMPACT ON } \\
\text { PROJECT }\end{array}$ & $\mathbf{L}$ & $\mathbf{S}$ & G & $\mathbf{w}$ & MITIGATION ACTIONS & $\mathbf{L}$ & $\mathbf{S}$ & G & $\mathbf{W}$ \\
\hline 1 & $\begin{array}{l}\text { Accident or } \\
\text { emergency cases at } \\
\text { the site area }\end{array}$ & $\begin{array}{l}\text { Harm worker life } \\
\text { during Installation } \\
\text { and WEC operation }\end{array}$ & $\mathrm{L}$ & $\mathrm{H}$ & C & 3 & $\begin{array}{l}\text { Apply the assistant of expertise } \\
\text { OSHA Standard (for exp: Safety } \\
\text { Officer) }\end{array}$ & $\mathrm{L}$ & $\mathrm{L}$ & $\mathrm{N}$ & 1 \\
\hline 2 & $\begin{array}{l}\text { Lack of security } \\
\text { and safety system } \\
\text { during WEC } \\
\text { construction and } \\
\text { operation }\end{array}$ & $\begin{array}{l}\text { The WEC or } \\
\text { integrated } \\
\text { equipment can be } \\
\text { stolen by theft or } \\
\text { local people }\end{array}$ & M & $\mathrm{H}$ & B & 4 & $\begin{array}{l}\text { Establish Site Office and } \\
\text { Watchkeeper, Assistant by } \\
\text { Maritime Agencies such as RMN, } \\
\text { APMM, and Marine Police }\end{array}$ & $\mathrm{L}$ & $\mathrm{L}$ & $\mathrm{N}$ & 1 \\
\hline 3 & $\begin{array}{l}\text { Loss of accessories } \\
\text { and equipment of } \\
\text { WEC platform from } \\
\text { theft }\end{array}$ & $\begin{array}{l}\text { WEC unable to } \\
\text { operate and } \\
\text { generate the } \\
\text { required power }\end{array}$ & $\mathrm{L}$ & $\mathrm{H}$ & C & 3 & $\begin{array}{l}\text { Establish Site Office and } \\
\text { Watchkeeper, Assistant by } \\
\text { Maritime Agencies such as RMN, } \\
\text { APMM, and Marine Police }\end{array}$ & $\mathrm{L}$ & $\mathrm{L}$ & $\mathrm{N}$ & 1 \\
\hline 4 & $\begin{array}{l}\text { Loss of accessories } \\
\text { and equipment of } \\
\text { battery house from } \\
\text { theft }\end{array}$ & $\begin{array}{l}\text { WEC unable to } \\
\text { operate and } \\
\text { generate the } \\
\text { required power }\end{array}$ & $\mathrm{L}$ & $\mathrm{H}$ & C & 3 & $\begin{array}{l}\text { Establish Site Office and } \\
\text { Watchkeeper, Assistant by } \\
\text { Kuantan Port security and } \\
\text { equipped the battery house } \\
\text { with CCTV }\end{array}$ & $\mathrm{L}$ & $\mathrm{L}$ & $\mathrm{N}$ & 1 \\
\hline
\end{tabular}

5 Risk of a collision on the WEC

platform by ships in of Kuantan Port the areas

route Effects on the safety

L $\quad$ E $\quad$ A 5

Placement of specific lightings on WEC, usage of the particular colouring of the WEC buoy, giving notice to Mariners, establishing symbol in the Kuantan Nautical Chart, and making sure that the WEC is following Marine Department rules and regulation

\section{Project grade of risk before mitigation} mitigation
L $\quad M \quad D \quad 2$ 
The project grade of risk can be determined from and after the mitigation action occurs from the risks obtained from each cluster or team above. The summary of the project grade is shown in the tables below.

\section{Table 11.}

Project grade for each team before mitigation.

\section{BEFORE MITIGATION}

\begin{tabular}{lll}
\hline No. & Risk Group & Grade \\
\hline 1. & Project Management & 2.8 \\
\hline 2. & Hydrography & 2.2 \\
\hline 3. & Mechanical & 3.6 \\
\hline 4. & Electrical & 4.0 \\
\hline 5. & Civil & 2.8 \\
\hline 6. & Safety and Security & 3.6 \\
\hline Average & Risk Grade & $\mathbf{3 . 1 7}$ \\
\hline
\end{tabular}

Table 12.

Project grade for each team after mitigation.

\section{AFTER MITIGATION}

\begin{tabular}{lll}
\hline No. & Risk Group & Grade \\
\hline 1. & Project Management & 1.2 \\
\hline 2. & Hydrography & 1.0 \\
\hline 3. & Mechanical & 1.4 \\
\hline 4. & Electrical & 1.0 \\
\hline 5. & Civil & 1.0 \\
\hline 6. & Safety and Security & 1.2 \\
\hline Average & Risk Grade & $\mathbf{1 . 1 3}$ \\
\hline
\end{tabular}

The maximum grade of the risk before mitigation is allocated at grade 5, which represents mitigation actions, to reduce the Likelihood and Seriousness, to be identified and implemented as soon as the project commences as a priority. A benchmark of 2.5 is allocated after mitigation, half of the maximum grade of the risk. A set of a graph from before and after each group's mitigation action is shown in the figures below.

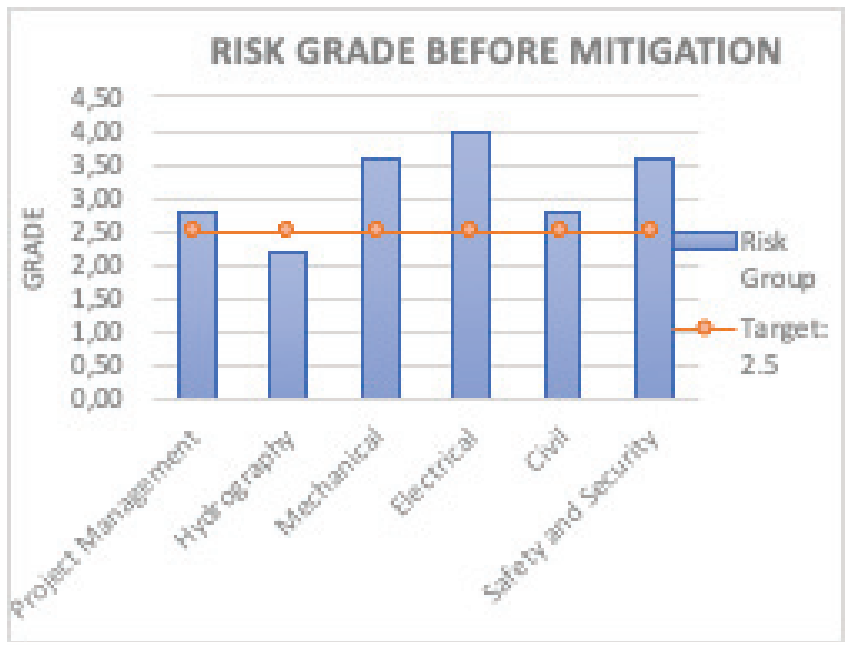

Figure 1.

Graph of risk grade before mitigation.

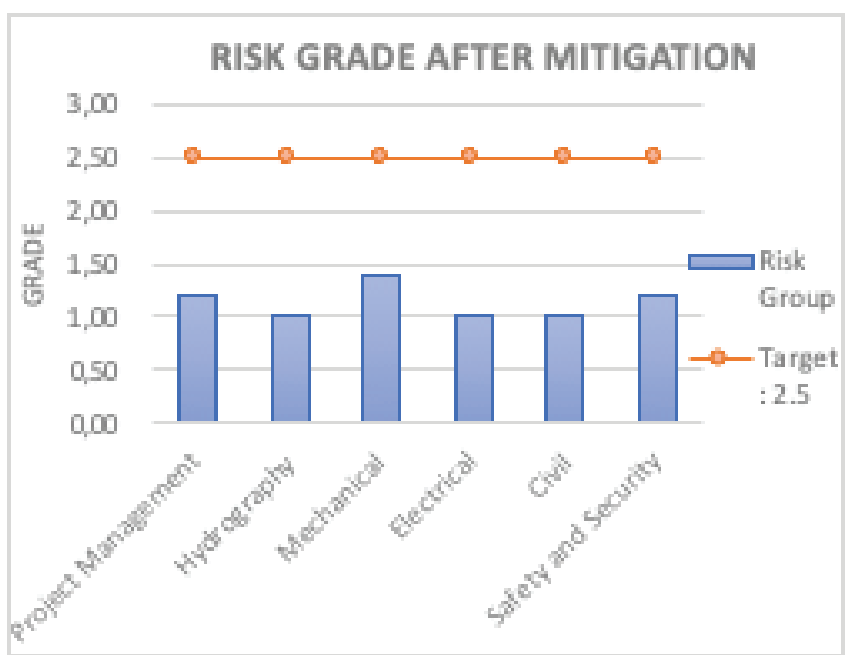

Figure 2.

Graph of risk grade after mitigation.

\section{DISCUSSION}

From the data obtained in the results and analysis, this research can concur that the risk is tolerable even before mitigation actions occur. Each team leader and their team 
members had given their feedback alongside the mitigation actions that need to be done to curb the risks.

By the project management team, the average project risk is graded at 2.8 , which refers to Table 4 , which is weighted at Grade C. It states that the mitigation actions decrease the Likelihood and Seriousness. It needs to be identified and its cost evaluated for possible action if funds permit. After mitigation action has been taken, the average project risk is graded at 1.2, and it is weighted at Grade N. It shows that no action is needed unless grading should increase over time.

For the hydrography team, the average project risk is graded at 2.2, as shown in Table 4, which is weighted at Grade D. It states that no action is needed unless grading is increasing over time. After mitigation action has been taken, the average project risk is graded at 1.0, and it is weighted at Grade N. It shows that no action is needed unless grading should increase over time.

By the mechanical team, the average project risk is graded at 3.6, as shown in Table 4, which is weighted at Grade B. It states that it needs to decrease the Likelihood and Seriousness to be identified, and appropriate actions need to be implemented during project execution. After mitigation action has been taken, the average project risk is graded at 1.4 , and it is weighted at Grade N. It shows that no action is needed unless grading should increase over time.

By the electrical team, the average project risk is graded at 4.0, the highest amount of risk. As shown in Table 4, it is weighted at Grade B. It states that it needs to decrease the Likelihood and Seriousness, be identified, and appropriate actions need to be implemented during project execution. After mitigation action has been taken, the average project risk is graded at 1.0, and it is weighted at Grade N. It shows that no action is needed unless grading should increase over time.

By the Civil team, the average project risk is graded at 2.8, as shown in Table 4, which is weighted at Grade C. It states that the mitigation actions decrease the Likelihood and Seriousness, it needs to be identified and evaluated in terms of cost for possible action if funds permit. After mitigation action has been taken, the average project risk is graded at 1.0, and it is weighted at Grade N. It shows that no action is needed unless grading should increase over time.

Lastly, by Safety and Security Team, the average project risk is graded at 3.6, as shown in Table 4, which is weighted at Grade B. It states that it needs to decrease the Likelihood and Seriousness to be identified, and appropriate actions need to be implemented during project execution. After mitigation action has been taken, the average project risk is graded at 1.2, and it is weighted at Grade N. It shows that no action is needed unless grading should increase over time.

From the total project risk of the overall team, this project is graded at 3.17, which is shown Table 4. It is weighted at Grade C. It states that the mitigation actions decrease the Likelihood and Seriousness. It needs to be identified and evaluated in terms of cost for possible action if funds permit. After the mitigation action has been taken, the overall average project risk is graded at 1.13. It is weighted at Grade N. It shows that no action is needed unless grading should increase over time.

\section{CONCLUSION}

Risk assessment has proven as a necessity before executing this project. It has given a general presumption of the possible risks, and necessary action must be taken to control the risks. From the risk assessment, the project's total risk grade before mitigation is 3.17 at Grade $C$. The project's entire risk grade after mitigation is 1.13 , which is at Grade N. The required allowable grade for the project should be less than 2.5 , half of the maximum Grade A weighting at 5 . In conclusion, this project is recommended to be carried out within Grade $\mathrm{N}$ of risk. All the mitigation procedures will be complied with, and no action is needed unless grading should increase over time.

\section{ACKNOWLEDGEMENT}

This paper is a part of the multidisciplinary research project of "Development of Optical Heave Buoy Wave Energy Converter (WEC) and is supported by the Ministry of Water, Land, and Natural Resources under grant H0001 - UPNM/2018/AAIBEKETTHA/TK/1/P6. The authors would like to thank everyone involved directly or indirectly or who have in any way assisted in this paper's making.

\section{REFERENCES}

AS/NZS4360, 2004. Risk Management Guidelines Companion to AS/NZS 4360:2004. Nature, 428(6983), pp.592-592.

BSI, 2018. BS ISO 31000 - 2018 BSI Standards Publication Risk management Guidelines. BSI Standards Publication, p.26.

Ferro, B.D., 2006. Wave and tidal energy. Refocus, 7(3), pp.46-48. Available at: http://dx.doi.org/10.1016/s1471-0846(06)70574-1.

Keshk, A.M., Maarouf, I. \& Annany, Y., 2018. Special studies in management of construction project risks, risk concept, plan building, risk quantitative and 
qualitative analysis, risk response strategies. Alexandria Engineering Journal, 57(4), pp.3179-3187. Available at:

http://dx.doi.org/10.1016/j.aej.2017.12.003.

Mueller, M. \& Wallace, R., 2008. Enabling science and technology for marine renewable energy. Energy Policy, 36(12), pp.4376-4382. Available at: http://dx.doi.org/10.1016/j.enpol.2008.09.035.

Okoro, U., Kolios, A. \& Cui, L., 2017. Multi-criteria risk assessment approach for components risk ranking - The case study of an offshore wave energy converter.
International Journal of Marine Energy, 17, pp.21-39. Available at: http://dx.doi.org/10.1016/j.ijome.2016.12.001.

Standard, D. of M., (2014). Malaysian Standard 1525:2014.

Sung, S.H., 2015. Quantitative and Qualitative Approach for IT Risk Assessment. Asiapacific Journal of Convergent Research Interchange, 1(1), pp.29-35. Available at: http://dx.doi.org/10.21742/apjcri.2015.03.04. 